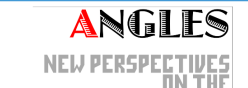
ANELOPHONE WORLD

\section{Angles}

New Perspectives on the Anglophone World

$12 \mid 2021$

COVID-19 and the Plague Year

\title{
Co-vidding Shakespeare: Creating Collective Videos from Shakespeare's Plays during the COVID-19 Pandemic
}

\section{Sarah Hatchuel}

\section{(2) OpenEdition \\ Journals}

Electronic version

URL: https://journals.openedition.org/angles/3415

DOI: 10.4000/angles.3415

ISSN: 2274-2042

Publisher

Société des Anglicistes de l'Enseignement Supérieur

\section{Electronic reference}

Sarah Hatchuel, "Co-vidding Shakespeare: Creating Collective Videos from Shakespeare's Plays during the COVID-19 Pandemic", Angles [Online], 12 | 2021, Online since 01 February 2021, connection on 22 December 2021. URL: http://journals.openedition.org/angles/3415; DOI: https://doi.org/10.4000/ angles. 3415

This text was automatically generated on 22 December 2021.

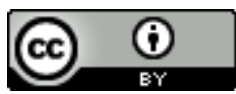

Angles est mise à disposition selon les termes de la Licence Creative Commons Attribution 4.0 International. 


\title{
Co-vidding Shakespeare: Creating Collective Videos from Shakespeare's Plays during the COVID-19 Pandemic
}

\author{
Sarah Hatchuel
}

1 As soon as lockdowns started all over the world in 2020, the story that Shakespeare wrote King Lear in quarantine at a moment when theatres had to close all over England because of the plague in the early $17^{\text {th }}$ century began to appear in the news and social networks (Dickson 2020). This anecdote might be true or not, but the fact that Shakespeare was soon connected to COVID and its dire cultural consequences is significant in itself and raises the following question: how can theatre practitioners, and artists in general, continue to create during a pandemic? And, for that matter, how can teachers in film and theatre studies continue to pass on knowledge and skills to their students? In what follows, I offer a particular account of how these two questions can interact.

\section{The year before the pandemic: Love's Labour's Won}

2 In September 2018, I started working as a professor in Film and Media studies at the University Paul-Valéry Montpellier 3, after being a professor in English Literature at the University of Le Havre Normandie. The shift in scholarly fields implied that, instead of teaching film to students who were already familiar with Shakespeare, I now had to convince film students that Shakespeare could bring much to their personal and professional journey, and to their understanding of theatre and film. At the MA level, I began teaching a second-semester class entitled "Filming Theatre" with a specific focus on Shakespeare's plays, to nearly a hundred students in Film and in Theatre. The aim was (and is) to explore the different ways of transforming a play written for the stage 
into an audio-visual object and to analyse the relations between an ephemeral live performance and a film that may preserve the memory of a show.

3 Through concrete examples, we examine the different modalities of the "theatrical film" (from mere recording to adaptation, from appropriation to "plays within films"), the several layers of discourses that allow screenwriters to turn a play-text to a film script, the ontological differences between the two arts, as well as the complex visions that films give of the theatre (especially through mirror films in which the embedded stage performance echoes the main story). I especially study scenes that are written specifically for the stage and which challenge filmic adaptation, such as the opening Chorus of Henry $V$ (which explicitly refers to the original conditions of performance at the Globe theatre) or the Dover Cliff scene from King Lear (the power of which precisely resides in the ambiguous presence of the cliff, created through Edgar's words addressed to his father). ${ }^{1}$

4 This course requires students to create a short video (5-10 minutes long) of a scene from a Shakespeare play, accompanied by a statement of intent describing the project and explaining the choices of mise-en-scène. With this work, students must show that they have acquired specific knowledge (how to situate their artistic endeavours in the history of Shakespeare on screen) and skills (how to find actors, or act themselves; how to write a script, film it, edit the rushes; add music and subtitles in postproduction). Students may adapt the text slightly, for instance adopting a queer perspective, but Shakespeare's scenes must still be recognized at first sight. If the film's language is French, the video must be subtitled in English; if the performance is in English, it must be subtitled in French - this task invites students to reflect on the fact that the work they produce will be made freely available to a large audience on YouTube. Students work in groups of three, four or five so that they can develop their abilities to collaborate and distribute tasks efficiently. They can organize their work on the project as they wish, ask amateur/professional actors or technicians to help them with the video and collaborate with MA English students. In May, they have to hand in their videos and intention notes, which I mark according to four criteria:

- relevance and originality of the video concept;

- clarity and quality of the script and of the acting;

- technical direction (image, sound, editing);

- subtitling (quality of the technical insertion; quality of the translation).

During the spring of 2019, nearly thirty Shakespearean videos were produced, adapting scenes from Macbeth, As You Like It, King Lear, A Midsummer Night's Dream or Romeo and Juliet, etc. Seven of them were real gems, with brilliant ideas. They were uploaded on a dedicated YouTube channel and publicly shown during the World Shakespeare on Screen Congress that was organised in Montpellier in September 2019. These seven videos were also placed on the Moodle learning platform to inspire the following class in 2020.

6 As far as Shakespearean videos are concerned, YouTube exemplifies several trends, identified and explored by Ayanna Thompson (2015): the archival impulse, preserving and sharing older performances of plays; the pedagogical impulse, often implemented by large theatre companies or Shakespearean institutions, which share educational commentaries on plays to be used as supplements for students and teachers alike; the parodic impulse, for instance providing a "rap" version of a play or debunking a play's patriarchal/sexist/racist ideology. ${ }^{2}$ According to Stephen O'Neill (2014: 3), YouTube can 
be of great value for students "since what emerges is a sense of Shakespeare as a body of knowledge that is shifting, incomplete and thus awaiting new interventions. In this way, YouTube Shakespeare not only has much to offer as archive, as a platform for vernacular expression, as a space to participate in what Shakespeare means."

In order to 'vid' Shakespeare, i.e. to create short videos out of his plays, upload them on internet platforms and take part in their own ways in this ever-shifting meaning of Shakespeare, my 2019 students adopted various strategies, exemplified in the seven selected films. The parodic impulse is not evident (except in the Variations on a balcony video, which offers different ways of performing the Romeo and Juliet balcony scene, following the sitcom codes, or the horror film conventions, for instance), but what is striking is the personal, original take on each Shakespearean scene. Students earnestly attempted to find an angle that had not been explored in previous filmic adaptations of the plays. In fact, videos already uploaded on YouTube were far less inspirational than cinematic versions analysed in class. Some students chose to shoot scenes indoors or outdoors with several actors together, before cutting and editing their rushes: Coemedia (As You Like It), Variations on a balcony, Juliette and Julia, A Midsummer Night's Dream (Act 3 scene 1). Others went for animated pictures, so that they didn't have to act or find actors and could focus on elaborating striking visual tableaux (Macbeth Act 4 scene 1). One group decided on revisiting the Dover Cliff scene in King Lear, challenged as they were by the different film versions that we had studied in the classroom (see 'The Cliff (King Lear)'). To a BBC radio production of the scene, they added clips taken from eclectic sources and produced a daring poetic film essay, based on landscape exploring, climbing and falling.

This media file cannot be displayed. Please refer to the online document http:// journals.openedition.org/angles/3415

Another group worked on the balcony scene in with gifted training actors based in New York (Sarah Bitar as Juliet and Fritz Bucker as Romeo). The idea behind the Balcony Screen video was to adapt the balcony scene to the social network era in which young people can meet randomly in chatrooms. The lovers' webcam-based conversation, with Juliet's 'window' screen placed above Romeo's, reproduces and remediates the verticality of the original meeting (see 'The Balcony Scene').

This media file cannot be displayed. Please refer to the online document http:// journals.openedition.org/angles/3415

These last two examples - one based on poetic montage, the other on digital meeting may have helped and guided the 2020 class when the virus hit.

\section{March-May 2020 : Love's Labour's Lost... or not}

10 From March 16, 2020, all universities closed down in France due to the COVID-19 pandemic. Teachers could no longer meet their students face to face; collective projects were threatened - especially the Shakespeare vidding project since students could neither meet to organize their work nor go out to shoot scenes. All their preparatory work that started in February on script writing, casting, location spotting, rehearsals, storyboarding and technical preparations first seem to have been all in vain. My role as 
a teacher was to reassure them in these difficult times and offer new assessment modalities. To protect themselves and others, I obviously encouraged them to respect lockdown and to favour communications by phone, email, video calls and collaborative work tools such as Framapad. I asked them to send me either the completed video (if they had managed to shoot their scenes before lockdown) or a very detailed script and storyboard (with detailed directions). The script had to be written in both French and English and give a precise idea of what the final video would have looked like.

Understandably, student groups overwhelmingly chose to hand in detailed scripts, some going as far as including photos of shooting locations, actors' pictures, precise shooting technical sheets and screen captures taken from well-known films to provide a sense of what their own videos would have looked like. Nevertheless, despite the fact that it was forbidden to go out, meet and shoot on location, two groups managed to find alternate ways and produce though-provoking videos. Coincidently or not, the two films were based on Macbeth, notably including excerpts from Lady Macbeth's sleepwalking/hand-washing scene, no doubt inspired by the world-wide prevailing discourse on hygiene to control the virus, but also by the nihilistic, apocalyptic feel of the lockdown situation. This nicely echoes the hand-washing Lady Macbeth meme that was circulated during the Coronavirus crisis (Smith 2020).

Figure 1: Lady Macbeth handwashing meme

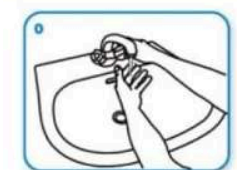

out, damned spot!

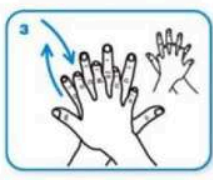

'tis time to do't.

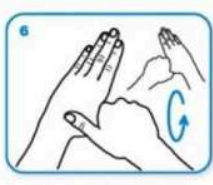

A soldier, and afeard?

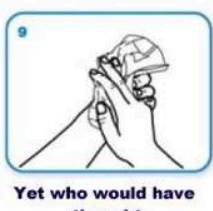

thought

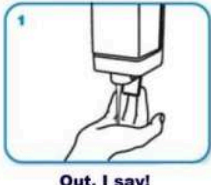

Out, I say!

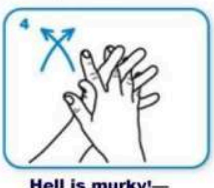

Hell is murky!-

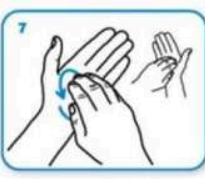

What need we fear who knows it,

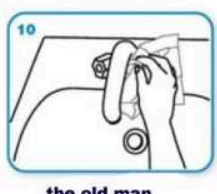

the old man

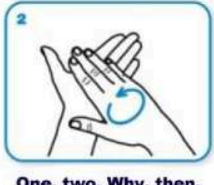

One, two. Why, then,

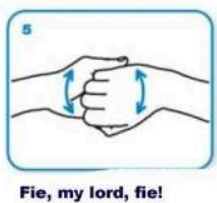

Fie, my lord, fie!
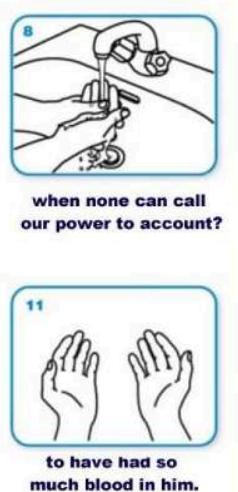

Source: https://www.penguin.co.uk/articles/2020/mar/the-history-behind-the-lady-macbethcoronavirus-meme.html

The first video, simply entitled Macbeth Act 5 scene 1, is the product of the collaboration between two students in theatre studies and three in film studies. They imagined that the sleepwalking scene is taking place during the COVID-19 crisis. In this rewriting, the 
scene becomes a remote interview between a female journalist (formerly the English doctor of Physic) and a female hospital GP (formerly the waiting gentlewoman).

This media file cannot be displayed. Please refer to the online document http:// journals.openedition.org/angles/3415

The two characters meet via a video-conferencing software and debrief their experience of watching the guilt-wracked Lady Macbeth as she recollects her horrid acts in a hospital bathroom. Her speech may have been captured by a surveillance camera without her knowledge or consent. Lady Macbeth's lines, which are originally interrupted by these two characters, become a full-fledged monologue that took place before the video call. Lady Macbeth is played by a man, thus appropriating Elizabethan same-sex acting practices but also playing with gender stereotypes and giving the character an even more tormented, twisted and scary look. The journalist and doctor talk and react with great empathy as they watch Lady Macbeth's recorded breakdown and express their amazement and sorrow over her mental health - a response which can be perceived as a discourse on the current state of the world affected by COVID- 19 .

The transformation of the Doctor into a journalist puts the stress on investigating questions as she looks for the origin of the disease, echoing the constant news coverage in hospitals and interviews with caregivers during the pandemic. In parallel, turning the bewildered gentlewoman into a helpless doctor resonates with the current discourse held by exhausted healthcare workers, marked physically and mentally by the shortage of masks and medical equipment, the lack of sleep and the fear of infecting their loved ones. The gentlewoman thus becomes the voice of Western science and institutions which, despite their self-proclaimed sophistication, have not coped well in managing the COVID-19 pandemic.

15 The second video is entitled Witches' Wishes and was made by four theatre students and two film students. Although it is also adapted from Macbeth, it offers a very different take on the play. Classic narration and representation here give way to an experimental and expressionist black-and-white montage, mixing speeches from the Witches and Lady Macbeth with images of different kinds that cogently illustrate them - shots of the Yellow Vests demonstrations and vigils in France, shots of downtown Montpellier taken before lockdown, images filmed at home by each student with their own cameras or phones.

This media file cannot be displayed. Please refer to the online document http:// journals.openedition.org/angles/3415

The film gives simultaneously a sense of still-life (through Gothic ruins shot in extreme low angles, desolate attics, white statues, wooden masks, the skull of a cow, wood rotting in murky water...) and abounding, swarming life with shots of moving animals (dogs, horses, cats, snails and slugs) and unidentifiable humans (a running girl, a woman doing her hair in the shadow, feet repeatedly knocking on wood, muddy hands being washed in a sink). The film also works on the opposition between elemental nature (through shots of trees, gardens, flowers, river, fire) and human artefacts (abandoned castles, tables, stairs, jars filled with food). It also offers stark contrast between the macrocosmic (with regular shots of the Moon and the sky) and the prosaic (water flushed down the toilets). Extreme close-ups of mouths, tongues and meat being 
sliced up, as well as the slight reverberation of the voice-over and the constant change in image formats (from vertical shots taken by a phone to horizontal taken by a camera), create a nightmarish atmosphere. The devilish trinity of Witches is reflected in the three split screens, where three white horses appear. The smoke, bubbly water and statues of clay are also reminiscent of Orson Welles's 1948 film version (Welles 1948), but the video takes the canonic film to an experimental level where there is no longer any character nor story - just evanescence and pure experience. Much importance was given to extradiegetic sound. The students composed original music to irrigate the women's speeches, going for what they called "a post-apocalyptic folk style" to convey the dreamlike aspects turning into psychological nightmares. The music is at once scary, haunting and intoxicating, accompanying the voices of the mind: these inner voices, often heard with echoes, invite us to think in terms of schizophrenia and madness. With such weird mixture of images and sound, the video itself becomes the Witches' potion recipe.

In these two instances, the COVID crisis created constraints which acted as artistic catalysts for students: they started to pay attention to some situations in Shakespeare's plays that they might have overlooked otherwise and, more importantly, lockdown forced them to be more imaginative in the ways they made the videos, inserting videoconferencing platforms in their scripts or filming shots on their own and then using editing software to make a coherent video and give it an art-house feel. The pandemic thus provided the inspiration for the themes they broached but also stirred them into trying new formats that respected physical distancing and nonetheless circumvented lockdown. As far as teachers are concerned, lockdown revealed how valuable and essential face-to-face teaching is, but also how the link with students can be maintained via technological means, so that they never lose motivation, drive and hope in these exceptionally difficult times. These COVID Shakespearean videos (or Shakespearean COVID videos?) are, in fact, testimonies to the paramount effect this sanitary, economic and social crisis has had on our students, which perhaps represents for them what 9/11 has meant for my generation - a watershed event, one that creates a "before" and an "after", calling for a complete change in the world policies and equilibriums (a change which, unfortunately, has not yet happened). The statements of intent that students have written to accompany their videos, denouncing the French government's mismanagement of the sanitary crisis and the destruction of public medical services, give me hope that this generation will be more politically aware and more ready to fight than we were, so that, to put it simply and brutally, the Anthropocene does not mean ultimately the extinction of our species.

\section{BIBLIOGRAPHY}

Dickson, Andrew. "Shakespeare in lockdown: did he write King Lear in plague quarantine?" The Guardian. 22 March 2020. https://www.theguardian.com/stage/2020/mar/22/shakespeare-inlockdown-did-he-write-king-lear-in-plague-quarantine 
Hatchuel, Sarah. Shakespeare, from Stage to Screen. Cambridge, Cambridge UP, 2000.

Hatchuel, Sarah. "Filming Metatheatre: the 'Dover Cliff' Scene on Screen.” Victoria Bladen, Sarah Hatchuel and Nathalie Vienne-Guerrin eds. Shakespeare on Screen: King Lear. Cambridge, Cambridge UP, 2019. 65-77.

O'Neill, Stephen. Shakespeare and YouTube: New Media Forms of the Bard. London, Bloomsbury, 2014.

Smith, Emma. "'Out damned spot': the Lady Macbeth hand-washing scene that became a Coronavirus meme.” Penguin.co.uk. 12 March 2020. https://www.penguin.co.uk/articles/2020/ mar/the-history-behind-the-lady-macbeth-coronavirus-meme.html

Thompson, Ayanna. “Othello/YouTube.” CUP Online Resources. In Sarah Hatchuel and Nathalie Vienne-Guerrin, eds. Shakespeare on Screen: Othello. Cambridge, Cambridge UP, 2015. https:// www.cambridge.org/download_file/866568

Welles, Orson. Macbeth. 107 mn. Mercury Productions. Republic Pictures. 1948.

\section{Videos}

The Balcony Screen. https://www.youtube.com/watch?v=SIovoISQF1k\&t=61s

The Cliff (King Lear). https://www.youtube.com/watch?v=Iov4wEryytc\&t=266s

Macbeth Act 1 scene 5. https://www.youtube.com/watch?v=rVue6j58Kvs

Witches' Wishes. https://www.youtube.com/watch?v=futXiEzOnQI\&t=363s

\section{NOTES}

1. On these filmic challenges, see Hatchuel (2000; 2019).

2. See for instance the "Sassy Gay Friend" series of videos, which revisit Romeo and Juliet, Hamlet or Othello: https://www.youtube.com/watch? v=SysESR_X8GE\&list=PLc6oA7ZelLySDydrW3b76vVHMLtw4hYzA

\section{ABSTRACTS}

This essay explores the pedagogical and artistic consequences of the COVID crisis on the "Filming Theatre" MA course at the University of Paul-Valéry Montpellier 3, in which students have to create short videos from Shakespeare's plays.

Cet article examine les conséquences du COVID, en matière pédagogique et artistique, sur le cours « Filmer le théâtre » du Master Cinéma à l'université Paul-Valéry Montpellier 3, cours dans lequel les étudiants et étudiantes doivent réaliser de brèves vidéos à partir des pièces de Shakespeare. 
INDEX

Mots-clés: Shakespeare William, vidéo, film, enseignement, COVID-19

Keywords: Shakespeare William, video, film, teaching, COVID-19

\section{AUTHOR}

\section{SARAH HATCHUEL}

Sarah Hatchuel is Professor of Film and Media Studies at the University Paul-Valéry Montpellier 3 (France) and former president of the Société Française Shakespeare. She has written extensively on adaptations of Shakespeare's plays (Shakespeare and the Cleopatra/Caesar Intertext: Sequel, Conflation, Remake, Fairleigh Dickinson University Press, 2011; Shakespeare, from Stage to Screen, Cambridge University Press, 2004; A Companion to the Shakespearean Films of Kenneth Branagh, Blizzard Publishing, 2000) and on TV series (Lost: Fiction vitale, PUF, 2013; Rêves et series américaines: la fabrique d'autres mondes, Rouge Profond, 2015; The Leftovers: le troisième côté du miroir, Playlist Society, 2019). She is general coeditor of the CUP Shakespeare on Screen collection and of the online journal TV/Series. Contact: s_hatchuel [at] hotmail.com 